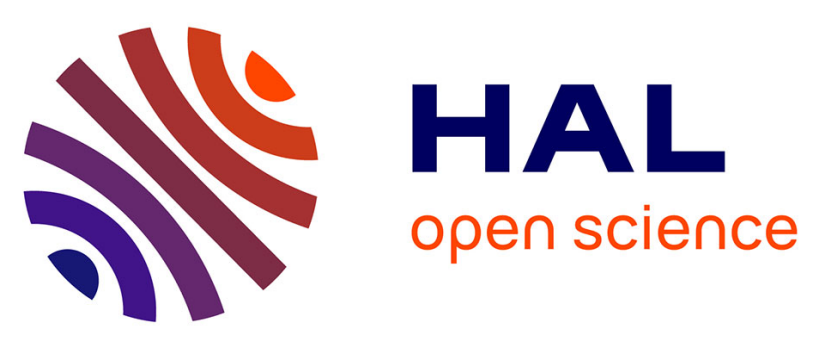

\title{
Inherited Creutzfeldt-Jakob disease in a Dutch patient with a novel five-octapeptide repeat insertion and unusual cerebellar morphology.
}

Casper Jansen, John van Swieten, Sabina Capellari, Rosaria Strammiello, Piero Parchi, Annemieke Rozemuller

\section{To cite this version:}

Casper Jansen, John van Swieten, Sabina Capellari, Rosaria Strammiello, Piero Parchi, et al.. Inherited Creutzfeldt-Jakob disease in a Dutch patient with a novel five-octapeptide repeat insertion and unusual cerebellar morphology.. Journal of Neurology, Neurosurgery and Psychiatry, 2009, 80 (12), pp.1386. 10.1136/jnnp.2008.169359 . hal-00552754

\section{HAL Id: hal-00552754 \\ https://hal.science/hal-00552754}

Submitted on 6 Jan 2011

HAL is a multi-disciplinary open access archive for the deposit and dissemination of scientific research documents, whether they are published or not. The documents may come from teaching and research institutions in France or abroad, or from public or private research centers.
L'archive ouverte pluridisciplinaire HAL, est destinée au dépôt et à la diffusion de documents scientifiques de niveau recherche, publiés ou non, émanant des établissements d'enseignement et de recherche français ou étrangers, des laboratoires publics ou privés. 
Inherited Creutzfeldt-Jakob disease in a Dutch patient with a novel five-octapeptide repeat insertion and unusual cerebellar morphology.

C. Jansen, J.C. van Swieten, S. Capellari, R. Strammiello, P. Parchi and A.J.M. Rozemuller

C. Jansen, A.J.M. Rozemuller: Dutch Surveillance Centre for Prion Diseases, University

Medical Centre Utrecht, Heidelberglaan 100, P.O. Box 85500, 3508 GA, Utrecht, The

Netherlands.

J.C. van Swieten: Department of Neurology, Erasmus University Medical Center, 'sGravendijkwal 230, 3015 CE Rotterdam Rotterdam, The Netherlands.

S. Capellari, R. Strammiello, P. Parchi: Dipartimento di Scienze Neurologiche, Università di Bologna, Via Foscolo 7, Bologna 40123, Italy

Corresponding author: C. Jansen, Dutch Surveillance Centre for Prion Diseases, University Medical Centre Utrecht, Heidelberglaan 100, P.O. Box 85500, 3508 GA, Utrecht, The

Netherlands. Telephone number (+31) 88 7556565; Fax number (+31) 302544990 c.jansen@umcutrecht.nl

Keywords: Creutzfeldt-Jakob disease, prion protein, genetic CJD, base pair insertion, 120 base pair insertion.

Word count: 1568 


\begin{abstract}
An atypical case of inherited Creutzfeldt-Jakob disease (CJD) is described in a 35-year old Dutch woman, homozygous for methionine at codon 129 of the prion protein gene (PRNP). The clinical phenotype was characterized by slowly progressive cognitive decline and Parkinsonism. Neuropathological findings consisted of scanty spongiosis and only faint to absent immunohistochemical staining for the abnormal prion protein, $\mathrm{PrP}^{\mathrm{Sc}}$, with patchy deposits in the cerebellar cortex. Purkinje cells were abnormally located in the molecular layer of the cerebellum. Western blot analysis showed the co-occurrence of $\mathrm{PrP}^{\mathrm{Sc}}$ types 1 and 2 with an unusual distribution. Sequence analysis disclosed a novel $120 \mathrm{bp}$ insertion in the octapeptide repeat region of the $P R N P$, encoding five additional R2 octapeptide repeats. These features define an unusual neuropathological phenotype and novel genotype, further expanding the spectrum of genotype-phenotype correlations in inherited prion diseases and emphasizing the need to carry out pre-mortem $P R N P$ sequencing in all young patients with atypical dementias.
\end{abstract}




\section{Introduction}

Prion diseases or transmissible spongiform encephalopathies (TSE) are rare neurodegenerative disorders characterized by the accumulation of an abnormal isoform of the prion protein in the brain ${ }^{1}$. They can occur as sporadic, familial or acquired disorders. In humans, around $15 \%$ of prion diseases are inherited and associated with mutations in the prion protein gene $(P R N P)$ on the short arm of chromosome $20^{2}$. Over 30 different mutations in the protein encoding region of $P R N P$ have been described. ${ }^{3}$ They are all transmitted in an autosomal dominant manner and include point mutations in the $\mathrm{C}$-terminal domain of PRNP, leading to an amino-acid substitution or premature stop codon, and insertional mutations in the N-terminal domain, in the form of a varying number (1-9) of 24 base pair multiplets in the octapeptide repeat region of $P R N P^{4}$. The normal $P R N P$ octapeptide repeat region is located between codons 51 and 91, and comprises a nonapeptide [Pro-Gln-(Gly) ${ }_{4}$-Trp-Gly-Gln, designated R1], followed by four copies of the octapeptide [Pro-His-(Gly) ${ }_{3}$-Trp-Gly-Gln]. Based on silent polymorphisms three different octapeptide sequences can be discerned at the nucleotide level, designated R2, R3 and R4. The normal format of the entire octapeptide region is R1-R2-R2-R3-R4 ${ }^{5}$. Patients with octapeptide repeat insertions (OPRI) show a considerable degree of phenotypic variability, depending on the size of the base pair insertion, the type of protease resistant prion protein $\left(\mathrm{PrP}^{\mathrm{Sc}}\right)$ and the codon $129 \mathrm{Met} / \mathrm{Val}$ polymorphism ${ }^{6 ; 7}$. In this report, we describe the clinical course, neuropathological findings and the results of genetic studies in a Dutch patient with a novel five octapeptide repeat insertional mutation (5-OPRI) in PRNP. 


\section{Methods}

Case history: the patient presented with forgetfulness and difficulties in writing at the age of 35, after the birth of her second child. Her family noted that she had become increasingly absentminded and apathetic. Her clinical history was otherwise unremarkable. Her father had suffered from dementia and Parkinsonism from the age of 45 and died at the age of 55. At neurologic examination, two-and-a half years after the first symptoms, the patient was disoriented in time and place, exhibited echolalia, perseveration and disturbed visual perception. She had a masked face with vertical gaze palsy, and increased tone of the extremities. Neuropsychological evaluation revealed an intact memory with acalculia, agraphia and apraxia. Brain magnetic resonance imaging (MRI) showed generalised cortical atrophy without evidence of hyperintensity or atrophy of either the caudate nucleus or the basal ganglia (Figure 1a). The 14-3-3 test in cerebrospinal fluid (CSF) was negative. An electroencephalogram was not recorded. Genetic analysis revealed no abnormalities in the tau protein gene $(M A P T)$, the Presenilin 1 gene (PSEN1) or the Huntingtin gene. Over the next 3 years, rigidity increased with the appearance of a slight tremor in her right hand, without any beneficial effect on levodopa and amantadin treatment. She increasingly developed dysarthria and swallowing problems, and suffered from anxiety and panic attacks. She was admitted in a nursing home, where she died from bronchopneumonia at the age of 42, 92 months after the clinical onset of the disease.

Neuropathology: The brain was removed 24 hours after death. Samples of tissue from several brain regions were frozen at $-80^{\circ} \mathrm{C}$. Gross examination of the brain showed mild global atrophy. Histopathological examination was performed on 5- $\mu \mathrm{m}$-thick sections of formalinfixed and paraffin-embedded brain tissue blocks, after decontamination for 1 hour in concentrated formic acid. Haematoxylin and eosin stains, combined with Luxol-PAS-blue 
stains and immunohistochemistry, were performed using standard techniques. Monoclonal antibodies 3F4 (1:400, Signet Laboratories, Dedham, MA, USA) were used for immunohistochemical detection of the disease-associated form of the prion protein following pretreatment with proteinase $\mathrm{K}$.

Genetic analysis: Genomic DNA was extracted from frozen brain tissue using standard techniques. The open reading frame of the PRNP was amplified as previously described. ${ }^{8}$ The PCR product was visualized on a $2 \%$ agarose gel to detect potential insertions or deletions. The codon 129 genotype was examined by digestion with the restriction endonuclease Xce I (Fermentas). For sequence analysis, the PRNP fragment encoding the Nterminal region of PrP was purified by DHPLC (gradient conditions calculated by the software for 2 fragments, 300 to 700 in length, in the Wave Nucleic Acid Fragment Analysis System, Transgenomic) and peak capture. The DHPLC run on non denaturing conditions at $50^{\circ} \mathrm{C}$, allows, other than the removal of all non-incorporated PCR reagents, the separation between the two alleles if they have a difference in length. The collected fragments were than sequenced as previously described ${ }^{9}$ and run on a ABI 310 Sequencer.

Western Blot: Frozen tissues from the frontal, parietal, and occipital cortex, cingulate gyrus, caudate nucleus and cerebellum were homogenized and analyzed for the presence and type of protease-resistant $\operatorname{PrP}^{\mathrm{Sc}}$ using an established method ${ }^{10}$. The immunoblot profile of $\operatorname{PrP}^{\mathrm{Sc}}$ was

classified as type 1 (unglycosylated $\operatorname{PrP}^{\mathrm{Sc}}$ of $\mathrm{M}_{\mathrm{r}} 20-21 \mathrm{kD}$ ) or type 2 (unglycosylated $\mathrm{PrP}^{\mathrm{Sc}}$ of $\mathrm{M}_{\mathrm{r}}$ 18-19 kD) based on the classification system by Parchi et al. ${ }^{11}$

\section{Results:}

Neuropathology: At autopsy the brain weighed $970 \mathrm{~g}$ and showed global cortical atrophy. Frontal sectioning revealed a slightly pale substantia nigra but a clearly visible locus coeruleus. The ventricular system was moderately dilated, especially in the parieto-occipital 
region. Microscopic examination revealed only mild spongiosis and astrocytic gliosis. The spongiform changes were most evident in the second cortical layer of the frontal, temporal and parietal lobes (Figure 1b). In the parietal cortex, vacuoles were seen in the deeper layers as well. The hippocampus was relatively spared. The cerebellum showed a moderate gliosis of the molecular layer, but no spongiform changes. Most conspicuously, there was an unusual localization of Purkinje cells in the molecular layer of the cerebellum (Figure 1d and 1e). Immunohistochemical staining merely showed faint synaptic staining in the parietal and occipital cortex, with small $\mathrm{PrP}^{\mathrm{Sc}}$ positive patchy deposits in the occipital cortex and the molecular layer of the cerebellar cortex (Figure 1c, $1 \mathrm{f}$ and 1g). Microscopic examination of the remaining regions of the brain was unremarkable.

Genetic analysis: Restriction enzyme analysis showed homozygosity for methionine at codon 129 of the PRNP. Amplification of the octapeptide repeat region of the PRNP by PCR resulted in two fragments, one of which was larger than the expected size, suggesting the presence of an insertional mutation in one of the PRNP alleles. Sequencing of this PCR product demonstrated a 120 -bp insertion in the octapeptide repeat region, encoding five additional $\mathrm{R} 2$ repeats.

Western blot: Western blot analysis of brain homogenates demonstrated the co-occurrence of $\mathrm{PrP}^{\mathrm{Sc}}$ types 1 and 2 with an unusual distribution. In the samples taken from the frontal cortex, and the cingulate gyrus both types of proteins were clearly seen, the parietal cortex had only $\mathrm{PrP}^{\mathrm{Sc}}$ type 1 , the occipital cortex showed a dominant type 1 with only traces of type 2 , whereas the cerebellar cortex and caudate nucleus showed only type 2 (Figure 2). Glycosylation was consistent with that of $\mathrm{PrP}^{\mathrm{Sc}}$ in $\mathrm{SCJD}$ (Figure 2).

\section{Discussion}


Seventeen patients with six different 5-OPRI have been described so far in the literature ${ }^{6}$. As in other inherited prion diseases, these disorders show a considerable degree of phenotypic variability, partly accounted for by the codon $129 \mathrm{Met} / \mathrm{Val}$ polymorphism. Age at onset in codon 129 heterozygous patients is usually later (58.0 years) than in codon 129 homozygous patients (42.3 years). ${ }^{6}$ Approximately half of these patients show a disease duration of more than 60 months. Although the clinical and pathological features of 5-OPRI mutations are relatively well-known, genotype-phenotype correlation has not been clearly established, warranting the description of further genetic cases.

In this report, we describe a novel insertion mutation in $P R N P$, consisting of five extra $\mathrm{R} 2$ octapeptide repeats [R1-(R2)7-R3-R4]. The clinical phenotype in our patient was characterized by slowly progressive cognitive decline, parkinsonism, anxiety and a long disease duration of 92 months. Neuropathological findings included scanty spongiosis and faint synaptic or even absent immunohistochemical staining, except for small patchy deposits in the cerebellar cortex, without the characteristic perpendicular orientation to the meningeal outline, as described in other patients with insertion mutations ${ }^{8 ; 12}$. An intriguing finding, although described before in three other patients with a 5-OPRI mutation ${ }^{13}$, was the abnormal localisation of Purkinje cells in the molecular layer of the cerebellum. The type of abnormalities, combined with the absence of ataxia and significant cerebellar pathology, strongly suggest this defect as being longstanding and likely related to a developmental defect. Thus, although largely speculative, the observation may suggest a role of $\mathrm{PrP}^{\mathrm{C}}$ in cerebellar neuronal migration or in the elimination of misplaced Purkinje cells during development which likely involve the programmed cell death machinery, as recently suggested ${ }^{14}$. Furthermore, in absence of a specific histopathologic picture, the observation of 
misplacement of Purkinje cells in the molecular layer might be an helpful diagnostic clue prompting the suspicion of inherited prion disease with OPRI mutation.

Another interesting finding was the co-occurrence of $\operatorname{PrP}^{\mathrm{Sc}}$ types 1 and 2 in brain homogenates, as demonstrated by immunoblotting. To our knowledge, this has only been described once before in a patient with one extra octapeptide repeat in $P R N P$, who showed widespread spongiosis and diffuse synaptic immunoreactivity in all cortical lobes ${ }^{15}$. In light of the scanty spongiosis and faint immunohistochemical staining in the brain of our patient, the presence of type 2 protein is a peculiar finding, since in methionine homozygotes (MM) at codon 129 type 2 is usually associated with prominent spongiosis with confluent vacuoles and more consistent coarse and perivacuolar deposits of $\operatorname{PrP}^{\mathrm{sc}}$ in the cerebral cortex ${ }^{11}$.

Furthermore, type 2 in MM cases preferentially accumulates in the cerebral cortex ${ }^{11}$, whereas it was mainly detected in the striatum and cerebellum in the present case.

The 5-OPRI mutation in this patient was probably inherited in an autosomal dominant pattern, but a positive family history in patients with inherited prion disease is not obligate. In all patients with a clinical history of frontotemporal dementia or atypical dementia and abnormal localisation of Purkinje cells in the molecular layer of the cerebellum, inherited prion disease should always be considered and pre-mortem PRNP sequencing should be carried out. 


\section{Acknowledgements}

The tissue was obtained with help from The Netherlands Brain Bank (NBB), Netherlands

Institute for Neuroscience, Amsterdam. A written informed consent for the brain autopsy and the use of clinical information and tissues for research purposes has been obtained by the NBB. We are indebted to Wouter Kamphorst in the VU University Medical Centre, Amsterdam, The Netherlands, for his expertise in performing the autopsy.

The Corresponding Author has the right to grant on behalf of all authors and does grant on behalf of all authors, an exclusive licence (or non exclusive for government employees) on a worldwide basis to the BMJ Publishing Group Ltd and its Licensees to permit this article (if accepted) to be published in the Journal of Neurology, Neurosurgery \& Psychiatry editions and any other BMJPGL products to exploit all subsidiary rights, as set out in our licence (http://jnnp .bmjjournals.com/ifora/licence.pdf). 


\section{Legends to illustrations:}

Figure 1: MRI (a), microscopic findings (b, $d$ and e) and immunohistochemistry for prion protein (c, f and g). All sections are stained with Heamatoxylin and Eosin and the 3F4 antiPrP antibody, original magnification x4 (c), x10 (b, d and f) and x20 (e and g). Cortical and subcortical atrophy with ventricular dilatation is evident on T1-weighted images (a). T2weighted images also showed generalized cortical atrophy of both hemispheres with intact hippocampus, without hyperintense lesions (data not shown). FLAIR MRI was not performed. The neuropathological examination showed the presence of spongiosis in the superficial layers of the parietal cortex (b). Synaptic staining and small plaque-like deposits in the occipital cortex (c). Unusual localization of Purkinje cells in the molecular layer of the cerebellum, without spongiform changes ( $\mathrm{d}$ and e). Immunohistochemical staining shows PrP positive patchy deposits in the molecular layer of the cerebellar cortex ( $\mathrm{f}$ and $\mathrm{g}$ ).

Figure 2: Western blot analysis of $\mathrm{PK}$ treated $\mathrm{PrP}^{\mathrm{Sc}}$ extracted from frontal (FC), parietal (PC), and occipital cortex (OCC), cingulate gyrus (CI), caudate nucleus (CAU), and cerebellum (CE). A sample from a sCJDVV2 subject (lane 1) is included as positive control. Relative molecular masses are indicate in kilodaltons. 


\section{Reference List}

1. Prusiner SB. Prions. Proc.Natl.Acad.Sci.U.S.A 1998;95:13363-83.

2. Masters CL, Harris JO, Gajdusek DC, Gibbs CJ, Jr., Bernoulli C, Asher DM. Creutzfeldt-Jakob disease: patterns of worldwide occurrence and the significance of familial and sporadic clustering. Ann.Neurol 1979;5:177-88.

3. Kovacs GG, Trabattoni G, Hainfellner JA, Ironside JW, Knight RS, Budka H. Mutations of the prion protein gene phenotypic spectrum. J Neurol 2002;249:1567-82.

4. Gambetti P, Kong Q, Zou W, Parchi P, Chen SG. Sporadic and familial CJD: classification and characterisation. Br.Med.Bull. 2003;66:213-39.

5. Goldfarb LG, Brown P, McCombie WR, Goldgaber D, Swergold GD, Wills PR, Cervenakova L, Baron H, Gibbs CJ, Jr., Gajdusek DC. Transmissible familial Creutzfeldt-Jakob disease associated with five, seven, and eight extra octapeptide coding repeats in the PRNP gene. Proc.Natl.Acad.Sci U.S.A 1991;88:10926-30.

6. Mead S, Webb TE, Campbell TA, Beck J, Linehan JM, Rutherfoord S, Joiner S, Wadsworth JD, Heckmann J, Wroe S, Doey L, King A, Collinge J. Inherited prion disease with 5-OPRI: phenotype modification by repeat length and codon 129. Neurology 2007;69:730-8.

7. Mead S, Poulter M, Beck J, Webb TE, Campbell TA, Linehan JM, Desbruslais M, Joiner S, Wadsworth JD, King A, Lantos P, Collinge J. Inherited prion disease with six octapeptide repeat insertional mutation--molecular analysis of phenotypic heterogeneity. Brain 2006;129:2297-317. 
8. Capellari S, Vital C, Parchi P, Petersen RB, Ferrer X, Jarnier D, Pegoraro E, Gambetti P, Julien J. Familial prion disease with a novel 144-bp insertion in the prion protein gene in a Basque family. Neurology 1997;49:133-41.

9. Capellari S, Cardone F, Notari S, Schinina ME, Maras B, Sita D, Baruzzi A, Pocchiari M, Parchi P. Creutzfeldt-Jakob disease associated with the R208H mutation in the prion protein gene. Neurology 2005;64:905-7.

10. Parchi P, Notari S, Weber P, Schimmel H, Budka H, Ferrer I, Haik S, Hauw JJ, Head MW, Ironside JW, Limido L, Rodriguez A, Strobel T, Tagliavini F, Kretzschmar HA. Inter-Laboratory Assessment of $\operatorname{PrP}(\mathrm{Sc})$ Typing in Creutzfeldt-Jakob Disease: A Western Blot Study within the NeuroPrion Consortium. Brain Pathol. 2008.

11. Parchi P, Giese A, Capellari S, Brown P, Schulz-Schaeffer W, Windl O, Zerr I, Budka H, Kopp N, Piccardo P, Poser S, Rojiani A, Streichemberger N, Julien J, Vital C, Ghetti B, Gambetti P, Kretzschmar H. Classification of sporadic Creutzfeldt-Jakob disease based on molecular and phenotypic analysis of 300 subjects. Ann.Neurol. 1999;46:224-33.

12. Vital C, Gray F, Vital A, Parchi P, Capellari S, Petersen RB, Ferrer X, Jarnier D, Julien J, Gambetti P. Prion encephalopathy with insertion of octapeptide repeats: the number of repeats determines the type of cerebellar deposits. Neuropathol.Appl.Neurobiol. 1998;24:125-30.

13. Skworc KH, Windl O, Schulz-Schaeffer WJ, Giese A, Bergk J, Nagele A, Vieregge P, Zerr I, I, Poser S, Kretzschmar HA. Familial Creutzfeldt-Jakob disease with a novel 120-bp insertion in the prion protein gene. Ann.Neurol 1999;46:693-700. 
14. Jung AR, Kim TW, Rhyu IJ, Kim H, Lee YD, Vinsant S, Oppenheim RW, Sun W. Misplacement of Purkinje cells during postnatal development in Bax knock-out mice: a novel role for programmed cell death in the nervous system? J Neurosci. 2008;28:2941-8.

15. Pietrini V, Puoti G, Limido L, Rossi G, Di FG, Giaccone G, Mangieri M, Tedeschi F, Bondavalli A, Mancia D, Bugiani O, Tagliavini F. Creutzfeldt-Jakob disease with a novel extra-repeat insertional mutation in the PRNP gene. Neurology 2003;61:128891. 

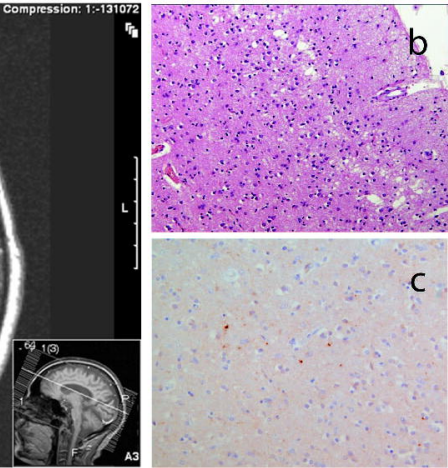

d

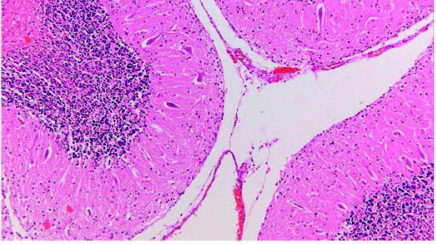

f

$$
\text { at? }
$$

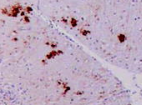


$26-$

19 -

$\begin{array}{lllllll}\text { sCJDVV2 } & \text { FC } & \text { PC } & \text { OCC } & \text { Cl } & \text { CAU } & \text { CE }\end{array}$ 